or fully four inches in excess of Ventnor. While the rainfall of the comparatively low-lying coasts of the Isle of Wight and Hants is about $30^{\circ} 00$ inches, the amount along the coast from Selsey Bill eastward as far as Folkestone is two inches less, but on the coast of Devon, from Lyme Regis to Start Point, it rises to from $33^{\circ} \circ$ to $37^{\circ} 6$ inches-figures of some importance in their relations to the sanataria of these coasts.

One of the most interesting results disclosed by these forty years' observations is the successive gradual increase of the rainfall decade by decade, the means being respectively, beginning, with the decade $1840-49,25^{\prime} 72$, $28.45,29^{\circ} \mathrm{I}$, and $3 \mathrm{I}^{\prime} \mathrm{I} I$ inches. This feature of the rainfall holds also in several other districts of the United Kingdom; whereas on the other hand other districts present a very different distribution during these forty years, that of some districts being just the reverse of Ventnor. The mean rainfall of Ventnor for the twenty years ending 1859 being 27.08 inches, and for the twenty years ending 1879 being $30^{\circ} 14$ inehes, points to the necessity there is that care be taken to employ the same terms of years in comparing the rainfall of different districts.

The mean temperature for the forty years is $51^{\circ} .6$; the coldest month being January, $4 \mathrm{I}^{\circ} .9$, and the warmest August, $62^{\circ} \%$. As January may be taken to represent the coldest months of the year, or the season when the climate of the Undercliff affords the greatest advantages to invalids, the following comparison of its temperature with that of other places in the South of England may be stated :-It exceeds the temperature of Sidmouth by $0^{\circ} \cdot 2$; Bournemouth by $0^{\circ} .6$; Osborne by $\mathrm{I}^{\circ} .2$; and Folkestone, Eastbourne, Brighton, and Clifton by $I^{\circ} \cdot 7$; but on the other hand its January temperature is lower than that of Torquay by $\mathrm{I}^{\circ} \mathrm{I}$; the extreme south-west of Cornwall by $2^{\circ} \cdot 6$; and Scilly by $4^{\circ} .4$. In this connection it is to be noted, as already pointed out, that along the coast to eastward the rainfall is less, and the climate therefore somewhat dryer; and to westward the rainfall is larger and the climate therefore wetter; and this latter remark applies with increased force as respects all places to the westward of Prawle Point.

The climatic advantages of the Undercliff, due to its southern insular position and distance eastward from the Land's End, by which the force of the west-south-west winds are much weakened before arriving there, are perhaps most apparent on examining the columns of minimum night temperatures. In this remark we refer to the general teaching of the figures, which indicate a remarkable protection against the inroads of low temperatures, with their malignant influence as respects a large class of invalids; and not to such singular temperature phenomena as the occurrence of $17^{\circ} \circ$ on January 22 last, during the great snowstorm of that period, for if great or exclusive weight be given to such temperatures the winter climate of the Undercliff must yield to that of many insular situations in the north-west of Scotland.

As compared with London the mean temperature of the Undercliff is $2^{\circ} .4$ less in July, $0^{\circ} .8$ in August; but in September it is $0^{\circ} .7$, and in October $2^{\circ} .2$ higher. In other words the heat of summer is greatly mitigated on the south shores of the Isle of Wight, and prolonged further into the autumn months, thus greatly extending the time during which invalids might sit out in the open air with impunity.

Dr. Whitehead's book is handsomely bound, carefully got up and printed, and the tables are introduced to the reader by a well-written and sensible preface. When the work, however, passes into a second edition, one or two improvements might be introduced. A table of monthly mean temperatures of the several years might be given similar to that of the rainfall on pp. 29,30 . In this edition no mean temperatures of the months are included, and to ascertain these the whole of the temperatures must be copied out from pp. $\delta$ to 23 , and the averages struck. The table of monthly barometric means requires careful revision, several of them showing transposed and inverted figures, while a few others require to be compared with the original observations from which they are calculated-transpositions and inversions of figures not being so readily seen in barometric as in thermometric and rainfall averages. The work, however, is an exceedingly valuable addition towards a correct knowledge of the climatologies of the South of England, which holds out to invalids the best winter refuges of the British Islands.

\section{INTERNATIONAL GEOLOGICAL CONGRESS}

THE second session of the International Geological Congress was recently held at Bologna, commencing on Monday, September 26. About 200 geologists were present, but only eight of them represented the Englishspeaking nations. These were : Yrof. James Hall (representing the United States), Dr. T. Sterry Hunt (Canada), W. T. Blanford (Geological Survey of India), W. Topley (Geological Survey of England), Prof. T. McK. Hughes, J. A. Phillips, E. B. Tawney, and Col. Tabuteau.

The arrangements made for the Congress were admirable in every respect, thanks to the energy and forethought of Prof. Capellini and M. Giordano.

The first session of the Congress was held at Paris in 1878. At that meeting certain geologists were nominated to organise committees in each country to discuss and report upon the various questions requiring attention. These are classed in three main divisions: (I) the unification of geological nomenclature (of this committee Prof. Hughes was nominated president for England) ; (2) the unification of colours, signs, \&c., employed in geological maps and sections (of this Prof. Ramsay was nominated president for England); (3) nomenclature of species; on this subject no action has been taken in England. Prof. Hughes' committee has been for some time at work, and notices of its progress have at various times appeared in this journal. The Committee on Geological Maps was started in England much later, but a report of its work was read at the York meeting of the British Association. At that meeting the Association gave a grant of $25 l$. in aid of the proposed International Map of Europe.

Some preliminary meetings were held at Bologna on Sunday, September 25, but the real work of the week commenced next day, when the Congress was formally received by the Syndic and Municipality of Bologna. At the opening meeting the chair was occupied by M. Berti, Minister of Agriculture and Commerce, who had been deputed to represent the King. The chairman was supported by M. Q. Sella, honorary president, and M. Ed. Hebert, ex-president. The bureau was formed as follows :-President : Prof. Capellini ; Vice-presidents, representing various nations, amongst them-J. Hall (United States), Sterry Hunt (Canada), W. T. Blanford (India), Prof. Hughes (Great Britain), Prof. Daubrée (France), Prof. Torell (Sweden), \&c.; General Secretary: F. Giordano; Secretaries: Bornemann, Delaire, Fontannes, Pelar, Taramelli, Topley, Uzielli, and Zezi. The Congress had offered prizes for the best essays upon the colouring, \&c., of maps. These were awarded to MM. Heim of Zürich, Carpinski of St. Petersburg, Maillard of Lausanne.

At the conclusion of this meeting the Congress adjourned to the excellent new Geological Museum which has been formed under the direction of Prof. Capellini. The Via Zamboni, in which the Museum is situated, was lined by representatives of all the ancient trade guilds of Bologna, each with its banner. M. Sella took especial pains to explain to the American and English visitors the history and present position of these interesting old societies.

The first sittings of the Congress were devoted to a 
discussion of the names to be employed in describing the various groups of beds, on which subject a preliminary report had been prepared by $M$. Dewalque. English geologists have always used the term "formation" to denote a group of beds, sometimes large, sometimes small; thus we should speak of the Silurian formation or of the Liassic formation. The word is rarely used in this sense by Continental geologists; they use it only as descriptive of the mode of origin or mode of formation, or as descriptive of the nature of the material composing the rock. Thus they might speak of the "chalk formation," but never of the "cretaceous formation." It was necessary for the English to make some concession on this point, which should satisfy the representatives of other countries without unduly committing English geologists. Prof. Hughes proposed a resolution recommending the use of the word "formation" as far as possible in the Continental sense.

A long [discussion followed respecting the value to be attached to certain words in descriptive geology, and ultimately it was resolved to employ them in the following order, the most comprehensive term being placed first :-

\begin{tabular}{c|c} 
Divisions of sedimentary formations. & Corresponding chronological term. \\
Groupe & Cycle \\
Système & Période \\
Série & Époque \\
Étage & Age
\end{tabular}

With regard to the term Serie a difficulty occurred, in consequence of there being no precisely similar equivalent in the German or Russian languages. This question was referred to the Council, who recommended the use of the terms Série, Section, or Abtheilung as equivalent terms. Also as regards the term Assise (subdivision of Etage) a reservation was carried leaving each nation to choose the word which most nearly expresses the same meaning (beds, couches).

There was much more down for discussion, especially with reference to proposed uniformity of language, terminations of words, \&c. ; but it was resolved to postpone these questions till the next meeting of the Congress, by which time it might be possible to arrive at some common terminology for eruptive rocks, \&c.

The second part of the work of the Congress related to the colours and signs employed in geological maps. On this subject a general report had been drawn up by Prof. Renevier, based upon the reports of various national committees. Much has been said about the solar spectrum and its order of colours, and Prof. Renevier's resolution, as originally drawn up, proposed a system of colour based on this natural order; but so many and important deviations from this natural order were recommended by different nations, that it was thought better to omit all reference to the solar spectrum. Resolutions were passed recommending the adoption of a common scale of colours for all nations, especially in view of general maps (travaux d'ensemble); but without reference to maps now in course of publication. The following colours were adopted :-

For crystalline schists of Pre-Cambrian age-bright rose-carmine. " ", ", unknown age-pale rose-carmine.

", Palæozoic rocks (question reserved for Map Committee).

, Trias-Violet.

", Lias-Dark blue.

, Jurassic-Blue.

," Cretaceous-Green.

"Tertiary group-Shades of yellow; the newer divisions to be the lighter tints.

The subdivisions to be shown by shades of the colour adopted, or by coloured lines; the darker shades denoting the older subdivisions. Sedimentary formations to be denoted by the initial Roman capital of the name of the formation; subdivision of formations to be shown, in addition to this, by the initial small letter of the name of the subdivision. Still smaller subdivisions to be shown by figures added to the other signs; the figures to be taken in chronological order-I denoting the oldest subdivision. Eruptive rocks to be denoted by the initial Greek capital of the name of the rock.

The Congress resolved to prepare and publish a geological map of Europe, and for this purpose a committee was appointed. Any committee having representatives of all the countries of Europe would be too large ; it was therefore necessary to limit the number of nations to be directly represented; at first this was fixed at five, but afterwards the committee was increased to eight. Great Britain received the largest number of votes, France coming second, Germany third. The committee was finally elected as follows:-Beyrich (for Germany, and also as director of the map); Daubrée (France); De Moeller (Russia); Giordano (Italy); Hauchecorne (as assistant director); Mojsisovics(Austro-Hungary); Renevier (Switzerland, and also as secretary); Topley (Great Britain). The map will be published at Berlin ; the scale was fixed at I : I, 500,000; the cost is estimated at about $2500 \mathrm{l}$; and application will be made to the various Governments of Europe for monetary aid.

In most of the countries not directly represented, arrangements will subsequently be made by the committee; but it was settled that Austria should take charge of Turkey, France of Algeria, \&c. (or of so much of that district as comes within the limit of the map), Great Britain of Palestine, it being hoped that much geological information, which may be available for this purpose, is in possession of the Palestine Exploration Society.

At a subsequent meeting it was arranged that a committee, formed for the most part of vice-presidents, should be formed to co-operate with the Map Committee with regard to questions of nomenclature, classification, \&c. Prof. Hughes represents England on this committee.

One sitting of the Congress was devoted to a discussion of the nomenclature of species. Upon this question only the French committee had sent a report, and no great amount of work was done. The Congress, however, recommended the use of a generic and a specific name, to be followed, when necessary, by that of the variety. The nomenclature to be Latin or Latinised. When the original name of the genus is not preserved, the name of the author of a new specific name is to be placed within brackets.

At the close of the Congress an excursion was made to Florence, Pisa, and the marble quarries of Carrara. For this free tickets or a special train were provided for all members. At each place the municipality received the Congress and did its utmost to render the excursion a success. At Florence the new Museum of Natural History was inspected, and then the Congress adjourned to the crypt of San Lorenzo to place a wreath on the tomb of Steno (who died in I687), and to hear an oration by Prof. Smidt of Copenhagen. At Pisa the Natural History Museum was visited, this being very rich in geological and prehistoric remains from the district.

An important result of the Congress has been the foundation of a Geological Society of Italy, of which Prof. Meneghini is president, Prof. G. Capellini vicepresident, and M. Pantanelli secretary. So much good geological work is now being done in Italy that it is of great importance to collect the scattered workers into one central society.

The next meeting of the Congress has been fixed for I884 at Berlin, with Dr. E. Beyrich as president; but preliminary meetings, with reference to the geological map of Europe, are to be held next year at Foix, in the Pyrenees (at the annual meeting of the Geological Society of France), and in I883 in Switzerland. It was generally understood that the fourth meeting of the Congress would be held in England. 